
MUSEUM.

\author{
By Charles Paul Alexander, \\ Of the Entomological Laboratory of Cornell University, Ithaca, New York.
}

\title{
INTRODUCTION.
}

The present paper is based on the extensive collections of insects taken on the island of Java in 1909 by Messrs. Owen Bryant and William Palmer. The crane-flies of this collection number about 150 specimens referable to some 60 species.

There has been a great amount of work done upon the crane-fly fauna of India and the East Indies in recent years and this has been accomplished for the greater part by the following workers:

Wiedemann in his Diptera exotica (1821) and Aussereuropäische zweiflügelige Insekten (1828) characterized a number of Javan species. His descriptions are excellent and very few of his species remain unrecognized. Francis Walker described a very considerable number of species, since he had access to the immense collections of the British Museum and William W. Saunders, the latter including most of the material taken by Alfred Russell Wallace in the Malay Archipelago. Doleschall (1856-1858) described a few species from the Dutch East Indies. Van der Wulp up until his death in 1899 published a number of articles dealing with the dipterous fauna of Java; these papers contain splendid descriptions and often beautifully colored figures by the author.

The living workers include Brunetti whose recent volume on the Diptera Nematocera of India (Fauna of British India, 1912) will do much to stimulate the study of this order in that country. Enderlein, who has published one very valuable paper (1912), most of his East Indian material being from Sumatra. Riedel in a short series of articles (Supplementa Entomologica, No. 1, August, 1912; Entomologische Mitteilungen, vol. 2, August, 1913), has worked over Sauter's Formosan collections. Edwards has given some very valuable contributions to our knowledge of the Oriental and African faunas; his most recent paper, a revision of the difficult genus Styringomyia (1914) is especially helpful. By far the most important work on the crane-flies of the island under consideration is that of Doctor de Meijere who has published a long series of valuable articles on the Dipterous fauna of Southeast Asia. 


\section{GEOGRAPHICAL DISTRIBUTION.}

The following notes will serve to give some idea of the geographic and topographic conditions under which the collection was made. It should be noted that the name "Pangranggo" is spelled in various ways. Reclus has it "Panggerango," and Wallace "Pangerango." The form adopted in the present paper is the one appearing on the printed insect labels of the collection.

Gedé and Pangranggo.- The western has a much greater mean elevation than the eastern section of the island, forming a plateau from 2,000 to 3,000 feet high. Here also the mountains are connected by lofty ridges or saddles, the former intervening valleys having been to a great extent filled in by outflows of lavas and showers of ashes and scoriae $* * *$ East of this pass follow the far loftier cones of Gedé or the "Great" (9,800 feet) which gives its name to a whole group, and the neighboring Mandala-Wangi which exceeds it by 200 feet. The Gedé, properly so called, has frequently ejected scoriae and from its bleached crater, about 4,000 feet in circumference, jets of vapor are still emitted; sulphur is also deposited on the encircling walls while copious thermal streams flow from the flanks of the mountain. Gedé is connected by a narrow ridge with another and far larger crater which from the Sala wall on the south to Panggerango on the north side has a circuit of about two and a half miles. It is wooded to the summit, terminating in an inclined terrace whence numerous rivulets rapidly converge in a broad stream which was till recently visited by the rhinoceros. From this terrace, the highest point of observation in west Java, a panoramic view is commanded of both seas, with the intervening hills and plains, forests, villages and surrounding plantations. ${ }^{1}$

Buitenzorg.-In 1774, Buitenzorg, that is "Sans Souci,"' was chosen as a site of an official health resort and this place has by successive enlargements become a vast residence, now usually occupied by the Governor Generals of the Dutch East Indies. Lying 880 feet above the sea on a wooded slope between the Liwong and Dani river valleys, Buitenzorg commands a superb prospect of the surrounding forest-clad gloomy gorges and undulating heights, rising in one direction toward Mount Salak, in another toward Gedé $* * *$ But Buitenzorg is not sufficiently elevated to be regarded as a sanitarium. Hence invalids and convalescents usually prefer the station of Sindang-Laya, which stands at an altitude of 3,560 feet on the northern slope of Gedé near the vast nursery grounds of Tjibodas. ${ }^{2}$

\section{Alfred Russell Wallace, who climbed the mountains of Gede and Pangranggo in 1861, describes his experiences as follows:}

By far the most interesting incident of my visit to Java was a trip to the summit of Pangerango and Gedeh Mountains, the former an extinct volcanic cone about 10,000 feet high, the latter an active crater on a lower portion of the same mountain range. * * The first mile was over open country which brought us to the forest that covers the whole mountain from a height of about 5,000 feet. The next mile or two was a tolerably steep ascent through a grand virgin forest, the trees being of great size and the undergrowth consisting of fine herbaceous plants, tree-ferns, and shrubby vegetation. I was struck by the immense number of ferns that grew by the side of the road. Their variety seemed endless and I was continually stopping to admire some new or interesting forms. I could now well understand what I had been told by the gardener, that 300 species had been found on this one mountain. *** Continuing our ascent, the road became narrow, rugged, and steep, winding zigzag up the cone, 
which is covered with irregular masses of rock and overgrown with a dense, luxuriant, but less lofty vegetation. We passed a torrent of water which is not much lower than the boiling point, and has a most singular appearance as it foams over its rugged bed, sending up clouds of steam and often concealed by the overhanging herbage of ferns and lycopodia, which here thrive with more luxuriance than elsewhere. ${ }^{1}$

On Mount Pangerango, between 5,350 feet and the top, 10,000 feet, the number of forest trees is about 350 species on the same area (300 hectares or 3 square kilometers) and about 1,400 species of non-arborescent phanerogams. ${ }^{2}$

\section{ACKNOWLEDGMENTS.}

I am indebted to the collectors of the material, Mr. Owen Bryant and Mr. William Palmer. The majority of the specimens, including the holotypes and uniques, are in the United States National Museum, and Mr. Frederick Knab, the custodian of the Diptera, has kindly afforded me every opportunity for studying this material. Most of the remaining insects are in Boston in the private collection of $\mathrm{Mr}$. C. W. Johnson, to whom I am grateful for many kindnesses, both at this time and often in the past.

\section{DESCRIPTION OF SPECIES.}

Family TIPULIDAE.

\section{Subfamily LIMNOBINAE.}

Tribe LIMNOBINI.

\section{Genus DICRANOMYIA Stephens.}

Dicranomyia Stephens, Catalogue of British Insects, vol. 2, 1829, p. 243.

\section{DICRANOMYIA SALTENS Doleschall.}

? Limnobia saltens Doleschall, Natuurk. Tijdschr. Nederl. Indie, vol. 14, 1857, p. 390 , pl. 11, fig. 3 .

One male of this species, Buitenzorg, Java; March, 1909 (Bryant and Palmer).

\section{DICRANOMYIA CUNEIFORMIS de Meijere.}

Dicranomyia cuneiformis de MeIJERE, Tijdschr. voor Entom., vol. 54, pp. 23, 24, 1911, pl. 1, fig. 2.

One female from Batavia, Java; April 1, 1909 (Bryant and Palmer).

DICRANOMYIA ALBITARSIS, new species.

Size large (wing of the male over $9 \mathrm{~mm}$.); wings dark, the tip brown; tarsi white.

Male.-Length, $7.4 \mathrm{~mm}$; wing, $9.5 \mathrm{~mm}$. Rostrum and palpi brownish black. Antennae dark brownish black. Head yellowish brown.

Thoracic dorsum light brown without distinct darker markings, the postnotum indistinctly trivittate with darker. Pleura dull brownish

${ }^{2}$ A. R. Wallace, The World of Life, 1911. 
yellow. Halteres brown. Legs, femora brown, somewhat darker at the tip; tibiae brown; fore tarsi with the basal two-thirds of the metatarsus brown, remainder white, hind tarsi entirely white. Wings infumed with darker, the tip brown, a narrow brown seam on $r$, veins dark brown; venation: (see pl. 42, fig. 1), $S c$ ending far beyond the origin of $R s, S c_{1}$, about three times as long as $S c_{2}, R s$ about three times as long as the deflection of $R_{4+5}$.

Abdominal tergites dark brown with about the apical half of each segment dull yellow, the sternites similar with about the apical twothirds dull yellow.

Habitat.-Java.

Holotype.-Tjibodas, Mount Gedé, Java; altitude, 4,500 feet (Bryant and Palmer).

\section{Type.-Cat. No. 19007, U.S.N.M.}

From the other described species with white tarsi, D. albitarsis differs as follows: D. saltens Doleschall and cuneiformis de Meijere have subcosta short, ending before the origin of the radial sector. $D$. longivena Edwards ${ }^{1}$ has the subcosta long but is a much smaller insect (wing $5 \mathrm{~mm}$. instead of $9 \mathrm{~mm}$.). D. kobusi de Meijere ${ }^{2}$ has the tibiae white with black rings, the radial sector short, oblique, cell 1st $M_{2}$ of the wings lacking, etc. D. novaeguineae de Meijere ${ }^{3}$ is larger, the tibiæ paler, the venation quite different in the very short subcosta, the shorter radial sector and the position of cell $1 s t M_{2}$.

DICRANOMYIA ATRESCENS, new species.

Body-coloration dark slate-gray; wings subhyaline with the stigma brown.

Male.-Length, $6.3 \mathrm{~mm}$; wing, $7.2 \mathrm{~mm}$. Head dark brownish black, the mouth parts injured.

Color of the thorax dark slate-gray with a sparse brown bloom. Halteres brownish black. Legs dark brown, the femora a little brighter than the other segments. Wings subhyaline, stigma rounded, brown, the margins not clearly defined; a brownish mark at the origin of $R s$; venation: $S c$ ending opposite the origin of $R s$.

Abdomen concolorous with the thorax; the pleurites of the hypopygium small, cylindrical; the ventral lobe large, almost globular, its inner margin produced entad into a sharp conical point that is fringed with long hairs along the caudal margin; the lobe itself is provided with scattered hairs and a dense short pubescence.

Habitat.-Java.

Holotype.-Tjibodas, Mount Gedé, Java; altitude, 8,000 feet (Bryant and Palmer).

Type.-Cat. No. 19008, U.S.N.M.

${ }^{2}$ Bijd. tot de Dierk., vol. 17, 1904, p. 91, pl. 8, figs. 5, 6, Tijd. voor Entom., vol. 56, 1913, p. 343, pl. 16, fig. 8.

8 Tijd voor Entom., vol. 58, 1915, p. 101, pl. 1, fig. 7. 
This insect is readily separated from the described species of the genus by its dark brownish black coloration and the peculiar shape of the ventral hypopygial lobe. The mouth parts are injured in my specimen and there is a possibility that it should more properly be referred to Geranomyia.

\section{DICRANOMYIA ERYTHRINA, new species.}

Size large (wing of the male over $10 \mathrm{~mm}$.); thorax reddish brown; wing with $S c$ very long.

Male.-Length, $9 \mathrm{~mm}$.; wing, $11.6 \mathrm{~mm}$. Rostrum short, light brown, the palpi dark brown. Head gray.

Thorax reddish brown, the dorsum scarcely darker. Halteres rather long, light brown; the knob dark. Legs light brown, the tibiae and tarsi darker. Wings with a faint yellowish tinge, stigma indistinct, brownish, veins brown; venation: (see pl. 42, fig. 2), Sc long ending just before the fork of $R s, S c_{1}$, about three times as long as $S c_{2}$, $R s$ about three times as long as the deflection of $R_{4+5}$.

Abdomen reddish brown, the apical three or four segments much darker brown.

Habitat.-Java.

Holotype.-Tjibodas, Mount Gedé, Java; altitude, 4,500 feet (Bryant and Palmer).

Type-Cat. No. 19009, U.S.N.M.

This species agrees closest with $D$. nongkodjadjarensis de Meijere ${ }^{1}$ but is readily separated by its much larger size (wing, $10 \mathrm{~mm}$.; in the other species, $7 \mathrm{~mm}$.).

\section{DICRANOMYIA EXCELSA, new species.}

Head grayish; thorax reddish, the dorsum a little darker; wings with the stigma distinct; abdomen brown.

Male.-Length, $7.6 \mathrm{~mm}$.; wing, $9 \mathrm{~mm}$.

Female.-Length, $8 \mathrm{~mm}$; wing, $8.7 \mathrm{~mm}$. Rostrum and palpi black. Antennae brown, the segments of the flagellum dark brown with a fine silky pubescence. Head dark slaty gray.

Thoracic dorsum shining dark brown, the pleura yellowish black. Halteres light yellow at the base, remainder dark brown. Legs, coxae and trochanters yellowish brown, remainder of the legs brown, the femora paler at the base. Wings hyaline, stigma oval, brown; narrow seams of brown on the cross-veins and the deflections of veins; veins brown; venation: (see pl. 42, fig. 3), $S c$ ending about midlength of $R s, S c_{1}$ twice as long as or as long as $S c_{2}$.

Abdomen with the tip of segment two yellowish, remainder of the abdomen dark brown.

Habitat.-Java. 
Holotype.-Male; Pangranggo, Java; altitude 9,000 feet (Bryant and Palmer).

Allotype.-Female; Tjibodas, Mount Gedé, Java; altitude 8,000 feet.

Paratypes.-Two males, with the allotype; altitude 8,000-9,000 feet, female, with the allotype; altitude 8,000 feet.

Type.-Cat. No. 19010, U.S.N.M.

Allied to $D$. alta de Meijere ${ }^{1}$ but the antennae are shorter, the thoracic dorsum shining, not dull, wings not suffused with brown and the size larger (wing, over $8 \mathrm{~mm}$.; in alta $6 \mathrm{~mm}$.).

\section{DICRANOMYIA SIMPLISSIMA, new species.}

Media with but one free branch attaining the margin; thoracic dorsum shiny black.

Female.-Length, $5 \mathrm{~mm}$.; wing, $6.3 \mathrm{~mm}$. Rostrum brownish yellow, palpi brownish black. Antennae brownish black. Head dark brown, dusted with gray, provided with numerous black hairs.

Pronotum brownish yellow. Mesonotal praescutum and the lobes of the scutum shiny black, remainder of the notum brownish. Pleura bright brownish yellow. Halteres brown. Legs, coxae, trochanters and femora at its base, bright yellow, remainder of the legs dark brown. Wings almost hyaline, stigma rather indistinct, brown, the veins brown; venation: (see pl. 42, fig. 4), $S c$ very short, ending far before the origin of $R s$; $R s$ short, arcuated, a little more than half as long as the deflection of $R_{4+5}$; vein $M$ simple, there being no cell 1st $M_{2}$ and $M_{3}$ fused with $C u_{1}$ throughout; basal deflection of $C u_{1}$ at the fork of $M$.

Abdomen dark brown, sternites and ovipositor yellowish.

Habitat.-Java.

Holotype.-Tjibodas, Mount Gedé, Java; altitude 9,000 feet (Bryant and Palmer).

Type.-Cat. No. 19011, U.S.N.M.

There are but four species of this genus known that have the upper branch of media unforked. These are D. whartoni Needham (Michigan ${ }^{2}$ which has a long radial sector. D. tenella de Meijere (Java) ${ }^{3}$ has a short sector, the thoracic dorsum shining yellow and is much smaller (length of the wing $4 \mathrm{~mm}$.). The only other species is $D$. carneotincta, new species, described below.

\section{DICRANOIMYIA CARNIOTINCTA, new species.}

Media with but one free branch attaining the margin; thoracic dorsum reddish yellow.

Male.-Length, 3mm.; wing, $4.3 \mathrm{~mm}$. Rostrum and palpi reddish brown, the latter rather darker colored. Antennae short, first

1 Tijd. voor Entom., vol. 56, 1913, p. 341, pl. 16, fig. 6.

2 23rd Report of the New York State Entomologist, 1907, pp. 211, 212, pl. 27, fig. 5.

a Tijdschr. voor Entom., vol. 56, 1911, p. 27, pl. 1, figs. 11-13. 
segment reddish yellow, flagellum brownish black. Head with the front whitish, remainder dark brown.

Thoracic dorsum reddish yellow, pleura dull yellow. Halteres brown. Legs, coxae, trochanters and the base of the femora light yellow, the latter darkening into brown, the tip quite dark, tibiae and tarsi brownish black. Wings hyaline, stigma rounded, indistinct, veins dark; venation: (see pl. 42, fig. 5), Sc short ending far before the origin of $R s$, this distance longer than the length of the radial sector; the radial sector shorter than the deflection of $R_{4+5}$.

Abdomen reddish yellow.

Habitat.-Malay Peninsula.

Holotype.-Singapore, Malay Peninsula; 1909 (Bryant and Palmer). Type.-Cat. No. 19012, U.S.N.M.

This species differs from $D$. tenella de Meijere, the only species that is at all close to it, in having a much shorter subcosta and a longer radial sector. In tenella, $S c$ ends but a short distance before the origin of $R s$ whereas in carneotincta this distance is longer than the length of the sector.

\section{Genus GERANOMYIA Haliday.}

Geranomyia Haliday, Entom. Magaz., vol. 1, 1833, p. 154.

GERANOMYIA NITIDA de Meijer̦e.

Geranomyia nitida de MerJere, Tijdschr. voor Entom., vol. 54, 1911, pp. 28, 29.

One female from Batavia, Java; April 1, 1909 (Bryant and Palmer). The wing is shown on plate 42 , figure 6 .

\section{GERANOMYIA LINEARIS, new species.}

Rostrum brownish black; mesonotum dark brown, the humeral angles yellow; pleura yellowish; wings tipped with brown.

Male.-Length, $5.8 \mathrm{~mm}$.; wing, $6.2 \mathrm{~mm}$.; rostrum, $2.6 \mathrm{~mm}$. Rostrum elongated, much longer than the head and thorax combined, dark brownish black. Palpi biarticulate, dark brownish black. Head dark gray.

Thoracic dorsum very dark brown, the humeral angles paler, yellowish. Pleura dull yellow. Halteres brown. Legs, coxae and trochanters yellowish, base of the femora yellowish, remainder of the legs brownish black. Wings suffused with brown, the stigma still darker, brownish; venation: (see pl. 42, fig. 7), Sc long, ending just before the fork of $R s$; $S c_{2}$ near the tip of $S c_{1}$, the two forks of $S c$ subequal in length; $R s$ twice as long as the deflection of $R_{4+5}$.

Abdomen dark brown, the ventral lobes of the hypopygium very long and slender, the tips more pointed, the lobe nearly three times as long as the pleura itself.

Habitat.-Java. 
Holotype.-Tjibodas, Mount Gedé, Java; altitude 4,500 feet (Bryant and Palmer).

Type.-Cat. No. 19013, U.S.N.M.

In de Meijeres key to the Javan species of this genus, ${ }^{1}$ this runs to G. nitida de Meijere which is a smaller insect with the pale margin to the thorax broader, the wings not so dark, etc.

\section{GERANOMYIA JAVANICA, new species.}

Thoracic dorsum light gray narrowly lined with black; wings spotted with brown.

Female.-Length, $6.8 \mathrm{~mm}$.; wing, $7 \mathrm{~mm}$.; rostrum, $3.5 \mathrm{~mm}$. Rostrum and palpi dark brownish black. Antennae and head dark brownish black.

Thoracic dorsum with the praescutum light gray narrowly lined with black; a broader median stripe including the dorsum of the pronotum and continuing to the suture; a much narrower, more delicate stripe on either side of this; lateral margin of the sclerite black; scutum with the lobes dark; scutellum gray, the caudal margin blackish. Pleura bluish gray, a yellow ventral stripe including the fore and middle coxae. Halteres brown. Legs, fore and middle coxae yellow; femora pale brown at the base, tip dark brown; tibiae and tarsi dark brown. Wings with a slight suffusion; membrane with brown blotches, about seven being on the costa, the third at the origin of $R s$, the fourth at the tip of $S c$, the fifth at the tip of $R_{1}$; brown marks along the cross-veins and deflections of veins; venation: (see pl. 42, fig. 8), Sc long, ending just beyond mid-length of $R s$; Rs between two and three times as long as the deflection of $R_{4+5}$.

Abdomen dark brownish black, ovipositor light brown.

Habitat.-Java.

Holotype.-Batavia, Java; April 1, 1909 (Bryant and Palmer).

Type.-Cat. No. 19014, U.S.N.M.

This species is allied to $G$. decemguttata de Meijere ${ }^{2}$ but the wingpattern is very much heavier and the thoracic pattern entirely different. It also resembles $G$. pulchripennis Brunetti ${ }^{3}$ but the thorax is grayish, not brownish yellow.

\section{Genus RHIPIDIA Meigen.}

\section{Subgenus RHIPIDIA Meigen.}

Rhipidia Meigen, Syst. Beschr., vol. 1, 1818, p. 153.

\section{RHIPIDIA (RHIPIDIA) JAVANENSIS de Meijere.}

Rhipidia javanensis de MeIJere, Tijdschr. voor Entom., vol. 54, 1911, pp. 31, 32.

Tjibodas, Mount Gedé, Java; altitude 4,500 feet, a male; altitude 8,000 feet, a male; altitude 9,000 feet, a male (Bryant and Palmer).

The wing has never been figured; it is shown on plate 42, fig. 9 .

${ }^{3}$ Fauna of British India, Diptera Nematocera, 1912, pp. 393, 394, pl. 8, fig. 1. 
Genus GONIODINEURA van der Wulp.

Goniodineura van der WuLP, Tijdschr. voor Entom., vol. 38, 1895, p. 37.

\section{GONIODINEURA NIGRICEPS van der Wulp.}

Goniodineura nigriceps van der WulP, Tidschr. voor Entom., vol. 38, 1895, p. 38 , pl. 2 , figs. $3-5$.

One female of this interesting crane-fly from Buitenzorg, Java; March, 1909. (Bryant and Palmer.) The venation is shown in plate 42 , fig. 10 . The specimen measures $6.8 \mathrm{~mm}$. in length with the wing $7.2 \mathrm{~mm}$.

\section{Genus LIMNOBIA Meigen.}

Limnobia Meigen, Syst. Beschr., vol. 1, 1818, p. 116.

\section{LIMNOBIA ANNULIFEMUR de Meijere.}

Limnobia annulifemur de Meijere, Tijdschr. voor Entom., vol. 56, 1913, pp. 344, 345, pl. 17, fig. 12.

One female of this beautiful Limnobia from Tjibodas, Mount Gedé, Java, at an altitude of 8,000 feet (Bryant and Palmer).

\section{Genus LIBNOTES Westwood.}

Libnotes Westwood, Trans. Entom. Soc. London, 1876, p. 505.

\section{LIBNOTES STRIGIVENA Walker.}

Limnobia strigivena Walker, Proc. Linn. Soc. London, vol. 5, 1861, p. 229.

Libnotes strigivena Osten Sacken, Berl. Ent. Zeitschr., vol. 31, 1887, p. 182.

Libnotes strigivena Skuse, Proc. Linn. Soc. N. S. Wales, ser. 2, vol. 4, 1889, p. 786 , pl. 21 , fig. 8 .

Libnotes strigivena de Meijere, Tijd. voor Entom., vol. 54, 1911, p. 35.

Libnotes strigivena de MeiJere, Tijd. voor Entom., vol. 56, 1913, p. 346.

One male from Mount Salak, Java, May 15, 1909 (Bryant and Palmer). It shows the following measurements: Length, $10.3 \mathrm{~mm}$; wing, $15.3 \mathrm{~mm}$.

\section{LIBNOTES, sp.}

A large species that comes close to poeciloptera Osten Sacken ${ }^{1}$ but the character of $R_{1}$ beyond the cross-vein $r$ is different from that described for this species. The material shows the following measurements: Male, length, 11-13 mm.; wing, 14-18 mm. Female, length, $16 \mathrm{~mm}$; wing, $18.5 \mathrm{~mm}$. Three male and one female from Tjibodas, Mount Gedé, Java, August 26, 1909, at an altitude of 8,000 feet, collected by Bryant and Palmer. The wing is shown on plate 43, fig. 11. 
LIBNOTES MONTIVAGANS, new species.

Thorax reddish, with a dark dorsal line; wings hyaline, sparsely spotted with brown.

Male.-Length, $5.8 \mathrm{~mm}$; wing, $7.4 \mathrm{~mm}$.

Female.-Length, $6 \mathrm{~mm}$; wing, $7.4 \mathrm{~mm}$. Rostrum, palpi, and antennae dark brown. Head dark brownish gray.

Thoracic dorsum brownish yellow, with a dark brown median stripe, which is narrowest in front, broader behind at the suture; lobes of the scutum dark brown. Pleura brownish yellow, brightest on the sternal sclerites. Halteres brown. Legs, coxae and trochanters dull yellow, remainder of the legs dark brown. Wings nearly hyaline, with brown markings as follows: a large stigmal spot, a smaller mark at origin of $R s$, veins comprising the cord and outer deflection of cell 1 st $M_{2}$ broadly seamed; tip of wing slightly infumed; veins brown; venation: (see pl. 43, fig. 12), $S c_{2}$ at the tip of $S c_{1}$ and of equal length; $R s$ about five times as long as the deflection of $R_{4+5} ; R s$ long, arcuated at its base.

Abdomen dark brown above, sternites indistinctly dull yellow.

Habitat.-Java.

Holotype.-Male, Tjibodas, Mount Gedé, Java; altitude, 8,000 feet (Bryant and Palmer).

Allotype.-Female, topotypic.

Type.-Cat. No. 19015, U.S.N.M.

This species belongs to the group containing species like forcipata de Meijere, famitiaris Osten Sacken, etc., forms that run very close to certain species of Dicranomyia.

L. familiaris Osten Sacken ${ }^{1}$ has the radial sector almost straight, about twice the length of the deflection of $R_{4+5}$; cell 1 st $M_{2}$ long, as long as $C u_{1}$ beyond the end of cell 1 st $M_{2}$; cross-veins seamed with brown. L. forcipata de Meijere ${ }^{2}$ has the basal deflection of $R_{4+5}$ much longer than the cross-vein $r-m$; basal deflection of $C u_{1}$ near the fork of $M$; dark markings on the wings sparse, etc.

LIBNOTES NERVOSA de Meijere.

Libnotes nervosa de Meijere, Tijdschr. voor Entom., vol. 54, 1911, pp. 36, 37, pl. 2 , fig. 21.

One male from Buitenzorg, Java, April 9, 1909, collected by Bryant and Palmer.

LIBNOTES NIGRICORNIS, new species.

Thorax yellowish brown; wings nearly hyaline.

Male.-Length, $6.6 \mathrm{~mm}$; wing, $7.4 \mathrm{~mm}$.

Female.-Length, $6.5 \mathrm{~mm}$.; wing, $7.5 \mathrm{~mm}$. Rostrum, palpi, and antennae brownish black. Head brownish gray. 
Thorax yellowish brown, the dorsum indistinctly darker; scutellum darker brown. Halteres rather short, knob brown, stem yellow. Legs, coxae, and trochanters dull yellow, remainder of the legs brown. Wings nearly hyaline, veins brown; venation: (see pl. 43, fig. 13), $S c$ long, extending far beyond the fork of $R s ; S c_{2}$ near the tip of $S c_{1}$.

Abdomen dark brown.

Habitat.-Java.

Holotype.-Male, Tjibodas, Mount Gedé, Java; altitude, 4,500 feet (Bryant and Palmer).

Allotype.-Female, topotypic.

Type.-Cat. No. 19016, U.S.N.M.

$L$. nigricornis is allied to L. forcipata de Meijere, but the antennae are dark throughout and the details of venation are different.

Tribe ANTOCHINI.

Genus PARATROPEZA Schiner.

Paratropeza Schiner, Verh. zool.-bot. Ges. Wien, vol. 16, 1866, p. 932.

\section{PARATROPEZA ORNATIPENNIS de Meijere.}

Gnophomyia ornatipennis de MeIJere, Tijdschr. voor Entom., vol. 54, 1911, pp. 47,48 , pl. 3 , fig. 34 .

Four males, Tjibodas, Mount Gedé, Java, altitude 4,500 feet (Bryant and Palmer). This is the first species of the genus to be found in the old World, the five species hitherto described being confined to the Neotropical region. It was described as a Gnophomyia but the whole habitus of the insect is Antochine and I believe that the insect should be referred to Paratropeza. The wing is shown on plate 43 , fig. 14 .

\section{Genus RHAMPHIDIA Meigen.}

\section{Subgenus RHAMPHIDIA Meigen.}

Rhamphidia Meigen, System. Beschr., vol. 6, 1830, p. 281.

\section{RHAMPHIDIA (RHAMPHIDIA) APICALIS, new species.}

Body-coloration brownish; wings hyaline tipped with brown.

Male.-Length, 5-5.8 mm.; wing, 5.7-6.3 mm.

Female.-Length about $7.4 \mathrm{~mm}$; wing, $7 \mathrm{~mm}$. Rostrum moderately elongated, much longer than the head, dark brownish black, the palpi dark brown. Antennae dark brown, rather elongated, in the male if bent backward, extending to the base of the abdomen; shorter in the female, extending about to the wing-root. Head dark brown.

Thoracic coloration varying from light to rather dark brown without distinct stripes, the pleura brighter colored, more yellowish. Halteres light brown. Legs, coxae brownish yellow; trochanters light brown; femora light brown basally passing into dark brown 
beyond the base; tibiae and tarsi dark brown. Wings hyaline, the tip narrowly brown; stigma distinct, oval, light brown; veins dark brown; venation, see plate 43 , fig. 15 .

Abdominal tergites dark brown, sternites light brown; valves of the female ovipositor very long and slender.

Habitat.-Java.

Holotype.-Male, Tjibodas, Mount Gedé, Java; altitude 4,500 feet (Bryant and Palmer).

Allotype.-Female, topotypic.

Paratypes.-One female, topotypic; 1 male, topotypic, altitude 8,000 feet.

Type.-Cat. No. 19017, U.S.N.M.

From $R$. kambangani de Meijere, ${ }^{1}$ from Java, $R$. ferruginosa Brunetti, ${ }^{2} R$. unicolor Brunetti, ${ }^{3}$ and $R$. inconspicua Brunetti $;^{4}$ the three last-named species from British India, this new form differs in the dark apex to the wings.

\section{EURHAMPHIDIA, new subgenus.}

Rostrum elongated as in Rhamphidia Meigen; differs from Rhamphidia, s. s., in the fusion of $R_{2+3}$ with $R_{4+5}$ for a considerable distance beyond the radio-median cross-vein. This character occurs in no other member of this tribe of crane-flies with the exception of the genus Rhampholimnobia, new genus, described below.

Type.-Rhamphidia niveitarsis Skuse.

\section{RHAMPHIDIA (EURHAMPHIDIA) NIVEITARSIS Skuse.}

Rhamphidia niveitarsis Skuse, Proc. Linn. Soc. N. S. Wales, ser. 2, vol. 4, 1889, pp. 791,792 .

Wings subhyaline, stigma oval, brown, veins brown; body-coloration light yellowish brown; abdomen with the segments tipped with yellowish; legs with the knees and the tarsi white.

Male.-Length, 5.6-6.6 mm.; wing, 6.4-7.1 mm.

Female.-Length, 6.8-7 mm.; wing, 7-7.2 mm. Rostrum rather elongated, longer than the head, brown, the palpi dark brown. Antennae short, if bent backward, not extending to the wing-root, the flagellar segments very short with numerous long pale hairs. Head brownish gray.

Thorax dull light yellow, the dorsum with a narrow dark brown median line; lobes of the scutum brown; postnotum brownish; in some specimens the thorax is darker, light brown, even the pleura being of this color. Halteres brown, paler at the base. Legs, coxae and trochanters dull brownish yellow; femora light yellowish brown,

1 Tijd. voor Ent., vol. 56, 1913, pp. 346, 347, pl. 17, fig. 13.

2 Fauna of British India, Diptera Nematocera, 1912, p. 418, pl. 8, fig. 8; pl. 11, fig. 11.

8 Idem, p. 419.

Idem, pp. 419, 420. 
the tip broadly white; tibiae with the base white, this space being a little shorter than the tip of the femora, remainder of the tibiae brown except the apical fourth which is white; tarsi white. Wings subhyaline, stigma oval, brown, veins brown; venation: (see pl. 43, fig. 16), the fusion of $R_{2+3}$ and $R_{4+5}$ beyond $r-m$ is longer than this cross-vein.

Abdominal tergites 3 to 7 dark brown on the basal two-thirds, yellowish on the apical third; sternites more yellowish; hypopygium dark brown.

Habitat.-New South Wales; Java.

Twelve specimens in the collection, as follows: Tjibodas, Mount Gedé, Java; 3 males, 2 females, at 9,000 feet; 1 male at 8,000 feet. (Bryant and Palmer). Pangranggo, Java; 4 males, 2 females, 9,000 feet. (Bryant and Palmer).

Skuse described this species from New South Wales and it has not been found since his time apparently.

\section{Genus RHAMPHOLIMNOBIA, nev genus.}

Antennae 15-segmented, the first segment elongated. Front between the eyes narrowed (in the female), on the lower surface of the head the eyes are contiguous. Rostrum very long, powerful, compressed, the tip apparantly broken in the unique type, length of the rostrum about equal to the head and thorax together, viewed from the side, the rostrum at the base is one-half as deep as the head, gradually narrowed toward the tip; viewed from above very narrow. Neck long and narrow. Venation: $R s$ elongate, gently arcuated at the base, $R_{2+3}$ and $R_{4+5}$ fused for a slight distance beyond the cross-vein $r-m ; R_{2+3}$ short, arcuated; cross-vein $r-m$ long, prominent; basal deflection of $C u_{1}$ before the fork of $M$.

Type.-Rhampholimnobia reticularis, new species.

This genus differs from Elephantomyia in the contiguity of the eyes beneath, the very powerful compressed rostrum, the venation as regards the basal fusion of $R_{2+3}$ and $R_{4+5}$, the position of the basal deflection of $C u_{1}$, etc.

\section{RHAMPHOLIMNOBIA RETICULARIS, new species.}

Coloration brown and yellow; wings hyaline, reticulated with brown.

Female.-Length, $8.2 \mathrm{~mm}$.; wing, $6.4 \mathrm{~mm}$.; rostrum (tip broken ?), $1.8 \mathrm{~mm}$. Rostrum dark brown. Antennae with the first segment gray, the second dark brownish black, third segment light yellow, remainder of the antennae light brown. Head light gray with several large clove-brown blotches on the middle of the vertex and occiput.

Cervical sclerites and pronotum brown; suture between the proand meso-nota yellow. Mesonotal præscutum light reddish brown 
with four darker brown lines; the middle pair longest, broader and more distinct behind; lateral stripes lying behind the pseudosutural foveae; region around the pseudosuture grayish yellow; scutum light brown, the lobes dark brown; scutellum and postnotum brownPleura dull gray, a dark brown blotch on the dorsal portions of the mesepisterna surrounding the anterior spiracle. Halteres light yellow. Legs, coxae dark brown; trochanters dull brownish yellow; remainder of the legs broken. Wings, costal cell and vein light yellow; remainder of the wing hyaline, veins brown; the membrane with numerous brown marks crossing the individual cells giving to the wing a reticulated appearance; venation: (see pl. 43, fig. 17), Sc rather long ending before the cross-vein $r-m ; R_{2+3}$ and $R_{4+5}$ fused for a short distance beyond cross-vein $r-m ; R_{2+3}$ short, arcuated, tending to be oblique; basal deflection of $C u_{1}$ before the fork of $M$.

Abdomen dark brown, valves of the ovipositor dull yellow.

Habitat.-Java.

Holotype.-Tjibodas, Mount Gedé, Java: altitude 4,500 feet. ant and Palmer.)

Type.-Cat. No. 19018, U.S.N.M.

\section{Genus ORIMARGA Osten Sacken.}

Orimarga Osten Sacken, Mon. Dipt. N. Amer., pt. 4, 1869, p. 120.

\section{ORIMARGA, sp.}

One injured specimen fom Buitenzorg, Java, March, 1909; this may be Orimarga borneensis Brunetti, ${ }^{1}$ as it agrees better with this insect than it does with $O$. javana de Meijere. ${ }^{2}$

\section{Genus STYRINGOMYIA Loev.}

Styringomyia Loew, Dipterol.-Beitrag., vol. 1, 1845, p. 6.

\section{STYRINGOMYIA, sp.}

A male and a female from Buitenzorg, Java, March, 1909 (Bryant and Palmer). A male from Pelaboean Ratoe, Java, October, 1909 (Bryant and Palmer).

This is probably $S$. jacobsoni Edwards ${ }^{3}$ but the genitalia are not as described and figured by the author. The elongate hair on the dorsal pleural appendage is much longer, the ventral pleural appendage is differently shaped, the spine on the tip of the pleura is longer and sharper, and the median appendage to the ninth sternite is not expanded, as shown in figure 35 of the article.

Whether or not all of the numerous species of this genus are valid is a question that can not be answered at this time. Mr. Edwards must be given all credit for giving to the world such a splendid revision of a very difficult group of insects. 
Genus ANTOCHA Osten Sacken.

Antocha Osten Sacken, Proc. Acad. Nat. Sci. Phila., 1859, p. 219.

ANTOCHA JAVANENSIS, new species.

Thorax grayish brown without distinct darker markings; wings whitish, stigma distinct; basal deflection of $C u_{1}$ before the fork of $M$.

Female.-Length, $4.2 \mathrm{~mm}$; wing, $4.8 \mathrm{~mm}$. Rostrum and palpi dark brown. Antennae brown. Head grayish brown.

Thoracic dorsum light grayish brown without distinct markings. Pleura grayish. Halteres yellow. Legs, coxae, and trochanters dull yellow; femora, tibiae, and tarsi light brown. Wings whitish, the stigma distinct, pale brown; veins brown. Venation: (see pl. 43, fig. 18), cross-vein $r$ indistinct, basal deflection of $C u_{1}$ before the fork of $M$.

Abdomen light brown.

Habitat.-Java.

Holotype.-Pelaboean Ratoe, Java; October 19, 1909 (Bryant and Palmer).

Type.-Cat. No. 19019, U.S.N.M.

This species agrees closest with Antocha indica Brunetti, ${ }^{1}$ but the color of the thorax is quite different, the wings whitish with the stigma distinct, etc.

\section{Genus ATARBA Osten Sacken.}

Atarba Osten Sacken, Mon. Dipt. N. Amer., pt. 4, 1869, 127.

\section{ATARBA JAVANICA, new species.}

Color of the body and wings yellowish; subcosta extending beyond the middle of the radial sector.

Female.-Length, $6.8 \mathrm{~mm}$; wing, $7.2 \mathrm{~mm}$. Rostrum, moderate in length, shorter than the head, dull yellow; the palpi brown. Antennae with the basal segments brownish yellow; the flagellum broken. Head, yellowish brown.

Thoracic dorsum dull yellow without well-defined darker markings. Pleura dull brownish yellow with an indistinct brown stripe; a slight grayish pruinosity above the middle coxae. Halteres dull yellow. Legs, coxae, and trochanters dull yellow; femora yellow, very narrowly tipped with dark brown; base of the tibiae very narrowly brown, remainder of the tibiae and tarsi dull yellow; the apical tarsal segments brown. Wings light yellow, the veins yellow. Venation: (see pl. 43, fig. 19), Sc long, ending beyond the middle of the radial sector; $R_{2+3}$ rather short and oblique, the space on the wing margin between $R_{1}$ and $R_{2+3}$ very much shorter than that between $R_{2+3}$ and $R_{4+5}$; basal deflection of $C u_{1}$ under the basal third of cell 1 st $M_{2}$. 
Abdominal segments dull yellow; the apical two-thirds of each segment dark brown.

Habitat.-Java.

Holotype.-Tjibodas, Mount Gedé, Java; altitude, 8,000 feet. (Bry* ant and Palmer.)

Type.-Cat. No. 19020, U.S.N.M.

Of the species of crane-flies described as Atarbae from the Oriental and African regions, Atarba flava Brunetti ${ }^{1}$ is the only one that is congeneric with the type, picticornis Osten Sacken of the United States. The other species are almost without exception members of the subgenus Leiponeura of the genus Gonomyia Meigen. The following may be mentioned:

Atarba lamellaris Speiser, ${ }^{2}$ Africa.

Atarba nebulosa de Meijere, ${ }^{3}$ Java.

Atarba pilifera de Meijere, ${ }^{4}$ Java.

Atarba diffusa de Meijere, ${ }^{5}$ Java.

Atarba javanica differs from $A$. flava as follows:

1. $S c$ short, ending just beyond the origin of $R s ; R_{2+3}$ long, the distance on the wing-margin between $R_{1}$ and $R_{2+3}$ at least as long as that between $R_{2+3}$ and $R_{4+5}$. (India) .................................. flava Brunetti.

$S c$ longer, ending beyond the middle of $R s ; R_{2+3}$ short, oblique, the distance on the wing-margin between $\mathrm{R}_{1}$ and $R_{2+3}$ much less than half that between

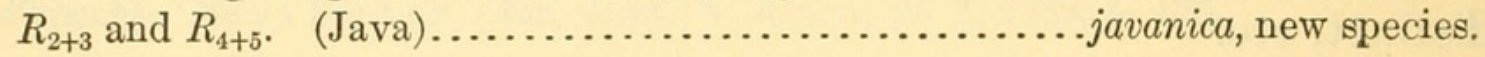

Tribe ERIOPTERINI.

Genus ERIOPTERA Meigen.

\section{Subgenus ERIOPTERA Meigen.}

Erioptera Meigen, Illiger's Magazine, vol. 11, 1803, p. 262.

ERIOPTERA (ERIOPTERA) JAVANENSIS de Meijere.

Erioptera javanensis DE MeIJERE, Tijdschr. voor Entom., vol. 54, 1911, pp. 45, 46, pl. 3 , fig. 28 .

One male from Pelaboean Ratoe, Java, October 16, 1909; one female, Buitenzorg, Java, March, 1909; collected by Bryant and Palmer.

\section{Subgenus ACYPHONA Osten Sacken.}

Acyphona Osten Sacken, Mon. Dipt. N. Amer., vol. 4, 1869, p. 151.

\section{ERIOPTERA (ACYPHONA) FENESTRATA de Meijere.}

Acyphona fenestrata DE Meijere, Tijdschr. voor Entom., vol. 56, 1913, pp. 352, 353, pl. 17, fig. 19.

One female from Tjibodas, Mount Gedé, Java; altitude, 8,000 feet; collected by Bryant and Palmer.

1 Fauna of British India, Diptera Nematocera, 1912, pp. 435, 436, pl. 8, fig. 15.

2 Beiträge zur Dipteren fauna von Kamerun, Deutsch. Ent. Zeitschr., 1913, p. 136, fig. 5, 6.

8 Studien über südostasiatische Dipteren, V, Tijd. voor Ent., vol. 54, 1911, p. 42, pl. 2, fig. 25.

1 Idem, p. 43, pl. 2, fig. 26.

${ }^{5}$ Idem, pp. $43,44$. 


\section{Genus GONOMYIA Meigen.}

\section{Subgenus GONOMYIA Meigen.}

Gonomyia Meigen, Syst. Beschr., vol. 1, 1818, p. 146.

GONOMYIA (GONOMYIA) BRYANTI, new species.

Cell 1 st $M^{2}=$ closed; wings subhyaline.

Male.-Length, $4.4 \mathrm{~mm}$; wing, $6 \mathrm{~mm}$. Rostrum, palpi, and antennae brownish black. Head gray.

Pronotum light yellow. Mesonotal praescutum and the lobes of the scutum dark brown; median line of the scutum and the scutellum light brown; postnotum dark brown. Pleura dull yellow. Halteres brown, the extreme base paler. Legs with the coxae and trochanters brown, remainder of the legs dark brown, unmarked. Wings hyaline or nearly so, stigma indistinct, veins brown; venation; (see pl. 44, fig. 20), $S c$ ending just beyond the origin of $R s$; Rs long, gently arcuated; $R_{2+3}$ long, about two-thirds the length of the sector; basal deflection of $R_{4+5}$ punctiform so that $R_{4+5}$ is in a line with $R s$.

Hypopygial pleurites moderately long, the dorsal appendage short, fleshy, pale; ventral appendage elongate, chitinized, provided with numerous long hairs and caruncles, its tip rather truncated; from the ventral inner side of the pleurite near its tip arises a small chitinized appendage shaped as in figure 49. (See pl. 47, figs. 48, 49.)

Abdomen dark brown; hypopygium yellow, its appendages black. Habitat -Java.

Holotype.-Male, Tjibodas, Mount Gedé, Java; altitude, 8,000 feet; August 26, 1909 (Bryant and Palmer).

Paratype.-Sex? , topotypic.

Type.-Cat. No. 19021, U.S.N.M.

Allied to $G$. affinis Brunetti ${ }^{1}$ in the venation but larger, the thoracic pattern different, legs much darker, etc.

\section{Genus MONGOMA Westwood.}

Mongoma Westwood, Trans. Entom. Soc. London, 1881, p. 364.

\section{MONGOMA CARINICEPS Enderlein.}

Mongoma cariniceps Enderlein, Zool. Jahrb., vol. 32, 1912, pp. 60, 61, fig. L 1.

A male and a female from Mount Salak, Java, May 15, 1909, collected by Bryant and Palmer. The female sex has never been described and I make this specimen the allotype. The coloration is quite as in the male, but the size is smaller (length, $11.5 \mathrm{~mm}$; wing, $10.3 \mathrm{~mm}$.). 
MONGOMA SAUCIA, new species.

Allied to trentepohlii Wiedemann; a brown crossband along the cord.

Female.-Length, about $4.5 \mathrm{~mm}$; wing, $4.8 \mathrm{~mm}$. Rostrum and palpi dark brown. Antennae long, if bent backward extending to just before the wing-root (in the female sex). Head dark.

Thoracic dorsum light brown without distinct darker stripes. Pleura rather darker brown. Halteres dull light yellow. Legs, coxae and trochanters dull brownish yellow, remainder of the legs light yellowish throughout. Wings hyaline or nearly so with pale brown markings as follows: tip of the wing brown except a large clear rounded spot in cell $R_{2}$; a broken crossband at the cord; a brown seam along $C u$; venation (see pl. 44, fig. 21).

Abdomen dark brown.

Habitat.-Java.

Holotype.-Tjibodas, Mount Gedé, Java; altitude, 7,800 feet (Bryant and Palmer).

Type.-Cat. No. 19022, U.S.N.M.

This species belongs to the trentepohlii group and is closest to trentepohlii Wiedemann ${ }^{1}$ but has a brown crossband at the cord.

\section{Genus CONOSIA van der Wulp.}

Conosia van der WulP, Tijdschr. voor Entom., vol. 23, 1880, p. 159.

\section{CONOSIA IRRORATA Wiedemann.}

Limnobia irrorata Wiedemann, Aussereur. zweifl. Insekt., vol. 1, 1828, p. 574.

Seven females from Buitenzorg, Java, January 10, 1909, to March 25, 1909; one female from Batavia, Java, February 26, 1909; the material collected by Bryant and Palmer. This insect is probably the most widely distributed crane-fly in the Old World. It ranges from northeastern Africa throughout Asia as far north as Japan and eastward along the East Indian islands to Australia.

Tribe LIMNOPHILINI.

Genus EPIPHRAGMA Osten Sacken.

Epiphragma Osten Sacken, Proc. Acad. Nat. Sci. Phila., 1859, p. 238.

EPIPHRAGMA SIGNATA de Meijere.

Epiphragma sigrata de MerJere, Tijdschr. voor Entom., vol. 54, p. 52, pl. 4, fig. 43.

One female from Tjibodas, Mount Gedé, Java, altitude 4,500 feet, collected by Bryant and Palmer.

${ }^{1}$ A ussereur. zweifl. Insekt., vol. 1, 1828, p. 551, pl. 6b, fig. 12. 


\section{Genus LIMNOPHILA Macquart.}

Limnophila MAcquart, Suite a Buffon, Dipteres, vol. 1, 1834, p. 95.

IIMNOPHILA AMICA, new species.

Body-coloration shiny brown; wings brown; cell $R_{2}$ very short, cell $M_{1}$ absent.

Male.-Length about $5.5 \mathrm{~mm}$.; wing, $6 \mathrm{~mm}$. Rostrum short, dull brown, the palpi brownish black. Antennae rather short, the segments of the flagellum oval; antennae dark brownish black throughout. Head dark brown, shiny.

Thoracic dorsum dark brown, shiny, the scutellum more yellowish. Pleura dull yellow. Halteres rather long, brown. Legs, coxae, and trochanters yellow; femora dark brown, paler at the base; tibiae black; tarsi broken. Wings pale brown, the stigma almost indistinct; veins dark brown; venation: (see pl. 44, fig. 22), $R s$ very long, straight; fork of $R_{2+3}$ short, much shorter than its petiole; cross vein $r$ far before the fork of $R_{2+3}$; cell $M_{1}$ absent; cells $R_{3}$ and $R_{5}$ in a line; basal deflection of $C u_{1}$ at about two-thirds the length of cell 1 st $M_{2}$.

Abdominal tergites dark brown, with a sparse gray bloom and long white hairs; sternites yellow, with a large dark brown blotch on the middle of each segment at the base.

\section{Habitat.-Java.}

Holotype.-Tjibodas, Mount Gedé, Java; altitude 4,500 feet. (Bryant and Palmer.)

\section{Type.-Cat. No. 19023, U.S.N.M.}

This insect suggests $L$. opaca de Meijere, ${ }^{1}$ but the cross vein $r$ is far before the fork of $R_{2+3}$, the cell $R_{2}$ quite differently shaped, etc.

LIMNOPHILA PALMERI, new species.

Body-coloration brown; wings light brown, stigma distinct; cell $M_{1}$ present.

Male.-Length, 6.3-7 mm.; wing, 7.4-7.5 mm. Rostrum brown, the palpi rather darker. Antennae very short, dark brown, the flagellar segments decreasing rapidly in size. Front dull yellow, remainder of the head dark grayish brown.

Thoracic dorsum dull yellow, rather shiny, with three dark brown stripes which are confluent behind; the lateral stripes short, beginning behind the pseudosutural region. Pleura dull brownish yellow. Halteres rather short, light brown, the knob darker. Legs, coxae, and trochanters dull yellow, femora brown, darkened beyond the base, tibiae and tarsi dark brownish black. Wings light brown, the stigma elongate, dark brown, veins dark brown; venation: (see pl. 44, fig. 23), Rs long, gently arcuated at the base; petiole of cell $R_{2}$ 
moderately long, a little longer than the deflection of $C u_{1}$; cell $M_{1}$ longer than its petiole; basal deflection of $C u_{1}$ just beyond the fork of $M$.

Abdominal tergites dark brown, the lateral margins of the segments paler brown; sternites dull brownish yellow.

Habitat.-Java.

Holotype.-Tjibodas, Mount Gedé,Java; altitude 5,000 feet. (Bryant and Palmer.)

Paratype.-Male, topotypic.

Type.-Cat. No. 19024, U.S.N.M.

The only regional form that agrees at all with this species is $L$. pallidicoxa Brunetti, ${ }^{1}$ but here the thorax is gray, not brown, etc. L. simplex Brunetti ${ }^{2}$ is much smaller; the name is preoccupied by Limnophila simplex Alexander ${ }^{3}$ from the Eastern United States.

\section{Subgenus DICRANOPHRAGMA Osten Sacken.}

Dicranophragma Osten Sacken, Proc. Acad. Nat. Sci. Phila., 1859, p. 240.

LIMNOPHILA (DICRANOPHRAGMA) REMOTA de Meijere.

Dicranophragma remota de Meijene, Tijdschr. voor Entom., vol. 56, 1914, pp. 1, 2, pl. 1 , fig. 1 .

One male from Buitenzorg, Java, April, 1909. Two males from Tjibodas, Mount Gedé, Java, altitude 4,500 and 9,000 feet. The material at hand was collected by Bryant and Palmer.

\section{Genus ULA Haliday.}

Ula Haliday, Entom. Mag., vol. 1, 1833, p. 153.

ULA JAVANICA, new species.

Body coloration brown, the pleura gray; wings light brown, cell 1 st $M_{2}$ very small.

Male.-Length about $5.5 \mathrm{~mm}$; wing, $7.4 \mathrm{~mm}$. Rostrum and palpi dark-brownish black. Antennae with the basal segments dark brownish black, the flagellum broken. Head gray, a blackish mark on the middle of the vertex and occiput.

Thoracic dorsum dark brown, rather darker medially with a sparse yellowish bloom, more grayish about the pseudosutural foveae. Pleura dark brown dusted with light whitish gray, especially on the ventral sclerites. Halteres light yellow, the knob darker. Legs, coxae elongate, yellow; trochanters brownish yellow; femora dull brownish yellow, the tip a little darker; tibiae and tarsi dark brown. Wings light brown, stigma very indistinct, darker, veins brown; venation: (See pl. 44, fig. 24), $S c_{2}$ anterior to the origin of $R s$ by a distance greater than the length of the basal deflection of $C u_{1}$, cell 
1st $M_{2}$ very small, the basal deflection of $C u_{1}$ just beyond the fork of $M$.

Abdomen dark brown, the hypopygium yellowish.

Habitat.-Java.

Holotype.-Tjibodas, Mount Gedé, Java; altitude 8,000 feet (Bryant and Palmer).

Type--Cat. No. 19025, U.S.N.M.

The discovery of this genus in the Oriental region is interesting. Ula has been placed in the tribe Pedicini hitherto, but it should be referred to the Limnophilini. I have reared the American species, Ula paupera Osten Sacken, ${ }^{1}$ from fungi, and the larva is quite Limnophiline in structure with nothing in common with the Pedicini.

\section{Tribe HEXATOMINI.}

Genus ERIOCERA Macquart.

Eriocera Macquart, Dipt. exot., vol. 1, pt. 1, 1838, p. 74.

ERIOCERA VERTICALIS Wiedemann.

Megistocera verticalis Wiedemann, Aussereur. zweifl. Insekt., vol. 1, 1828, p. 56.

Three males from Bantar Gebang, Java, October 21, 1909, collected by Bryant and Palmer. The specimens offer the following measurements: Length, 9.5-11 mm.; wing, 13.6-14 mm.; antennae, $42 \mathrm{~mm}$. The venation is shown in plate 44, fig. 25 .

ERIOCERA ACROSTACTA Wiedemann.

Limnobia acrostacta Wiedemann, Dipt. exot., vol. 1, 1821, p. 14.

Two males from Tjibodas, Mount Gedé, Java, April, 1909, collected by Bryant and Palmer. The specimens offer the following measurements: Length, 24-26 mm.; wing, 17.5-17.8 $\mathrm{mm}$. The venation is shown in plate 44 , fig. 26 .

\section{ERIOCERA BASILARIS Wiedemann.}

Limnobia basilaris Wiedemann, Dipt. exot., vol. 1, 1821, p. 15.

Two males and one female from Depok, Java, February 10, 1909. One male from Tjibodas, Mount Gedé, Java, April, 1909. The material was collected by Bryant and Palmer. The specimens offer the following measurements: Male, length, 15-17 mm.; wing, 10.2$12.5 \mathrm{~mm}$. Female, length, $15.2 \mathrm{~mm}$; wing, $10.4 \mathrm{~mm}$. The venation has never been figured, and is shown in plate 44, fig. 27 .

\section{ERIOCERA MESOPYRRHA Wiedemann.}

Limnobia mesopyrrha Wiedemann, Aussereur. zweifl. Insekt., vol. 1, 1828, p. 26.

One female from Buitenzorg, Java, March, 1909, collected by Bryant and Palmer. The specimen offers the following measure-

1 The Biology of the North American Crane Flies (Tipulidæ, Diptera) 3. The genus Ula Haliday; Journ. Ent. and Zool., vol. 7, 1915, pp. 1-9, pl. 1. 
ments: Length, $23 \mathrm{~mm}$; wing, $17 \mathrm{~mm}$. The wing, having never been figured, is shown in plate 44, fig. 28 .

ERIOCERA CINGULATA de Meijere.

Eriocera cingulata de MeiJere, Tijdschr. voor Entom., vol. 54, 1911, pp. 58, iš.

One female from Depok, Java, February 10, 1909, collected by Bryant and Palmer. The specimen is larger than de Meijere's types, measuring $11 \mathrm{~mm}$. in length, and with a wing-length of $13.8 \mathrm{~mm}$. In de Meijere's key to the Javan Eriocerae ${ }^{1}$ this appears as fasciata, new species. The wing has never been figured and is shown in plate 44, fig. 29.

\section{Subfamily CYLINDROTOMINAF. \\ Genus STIBADOCERA Enderlein.}

Stibadocera Enderlein, Zoöl. Jahrb., vol. 32, 1912, pp. 83, 84, fig. A 2.

This genus was erected by Enderlein with Stibadocera bullans Enderlein of Sumatra as the type. Cytindrotoma quadricellula Brunetti ${ }^{2}$ is a member of this genus. The species are all rather similar to one another and are separated mainly by slight differences of size, coloration, and venation. S. quadricellula (India) is the smallest species with a length of 6 to $6.5 \mathrm{~mm}$. in the male sex. The genotype, S. bullans (Sumatra) has the head bright ochre-yellow, the thorax ochre-yellow with pale brown dorsal stripes; the male has a length of $8.5 \mathrm{~mm}$., its wing, $8.7 \mathrm{~mm}$., its antenna, $11 \mathrm{~mm}$. The species described below as metallica, new species (Java), is the largest of the forms as yet described with a wing of $10 \mathrm{~mm}$. and an antennal length of $14 \mathrm{~mm}$. in the male sex; this species has the head and thorax with decided blue-black reflections.

The species of Stibadocera are remarkable for the length of the antenna in the male sex; in quadricellula it is described as being as long as the whole body (i. e., $6.5 \mathrm{~mm}$.), in the two other forms it is nearly half again as long as the body. The thorax is provided with numerous rather coarse punctures, except on the region occupied by the three praescutal stripes where the surface is quite free from punctures. The wings show the tip of $R_{1}$ present, cross-vein $r$ usually long and simulating a section of $R_{1}$, the cross-vein $r-m$ distinct, etc

The species of the genus range from India eastward to Java.

STIBADOCERA METALLICA, new species.

Size large (wing of the male, $10 \mathrm{~mm}$., antenna, $14 \mathrm{~mm}$.); head and thorax with decided blue-black reflections in certain lights.

Male.-Length, 8.8-9 mm.; wing, 10.2-10.8 mm.; antenna, 14 $\mathrm{mm}$. Rostrum and palpi brown. Antennae with the two scapal

1 Tijdschr. voor Entom., vol. 54, 1911, pp. 59, 60.

2 Records of the Indian Museum, vol. 6, 1911, p. 268; Fauna of British India, Diptera, 1912, p. 361, pl. 7, figs. $1,2$. 
segments dull yellow, flagellum with the segments greatly elongated, provided with long outspreading hairs, flagellum brown. Head smooth, blue-black.

Praescutum chestnut brown with three metallic blue-black stripes (in the paratype reddish blue), the surface of the sclerite covered by the stripes smooth, the rest punctate; scutum, scutellum, and postnotum dark brown, thickly punctured, especially the latter. Pleurae bluish brown, densely and coarsely punctured. Halteres long, slender, brown. Legs, coxae dull brown; trochanters dull yellow; femora and tibiae dull brownish yellow; tarsi darker brown. Wings brownish gray, veins brown; venation: (see pl. 45, fig. 30), vein $R_{1}$ present, distinct; cross-vein $r$ elongate, usually a little longer than the cross-vein $r-m$, sometimes shorter; $R_{2}$ atrophied at the tip. Abdomen dark brownish black, the sternites paler.

Habitat.-Java.

Holotype.-Pangranggo, Java; altitude 9,000 feet. (Bryant and Palmer.)

Paratype.-Male, Tjibodas, Mount Gedé, Java; altitude 8,000 feet. (Bryant and Palmer.)

Type.-Cat. No. 19026, U.S.N.M.

\section{Subfamily TIPUIINAF.}

Tribe DOLICHOPEZINI.

\section{Genus NESOPEZA Alexander.}

Nesopeza Alexander, Canadian Entomologist, vol. 46, 1914, p. 157.

\section{NESOPEZA GRACILIS de Meijere.}

Dolichopeza gracilis de MeIJere, Tijdschr. voor Entom., vol. 54, 1911, pp. 60, 61, pl. 4 , fig. 46.

Nesopeza gracilis Alexander, Canadian Entomologist, vol. 46, 1914, p. 157.

Two males from Tjibodas, Mount Gedé, Java, altitude 4,500 feet; two males, 9,000 feet (Bryant and Palmer). The material offers the following measurements: Length, 8.2-9.6 mm.; wing, 9.1-10.2 mm.

\section{Tribe CTEINOPHORINI.}

\section{Genus PSELLIOPHORA Osten Sacken.}

Pselliophora Osten Sacken, Berlin. Entom. Zeitschr., vol. 30, 1886, p. 165.

PSELLIOPHORA ARDENS Wiedemann.

Ctenophora ardens Wiedemann, Dipt. exot., vol. 1, 1821, p. 20.

One female, Buitenzorg, Java, March, 1909 (Bryant and Palmer). The insect has never been figured and is shown in plate 45, fig. 31 . 
PSELLIOPHORA COMPEDITA Wiedemann.

Ctenophora compedita Wiedemann, Dipt. exot., vol. 1, 1821, p. 21.

One male, one broken female, Depok, Java, March, 1909 (Bryant and Palmer). The wing is shown in plate 45, fig. 32 .

PSELLIOPHORA RUBRA Osten Sacken.

Pselliophora rubra Osten Sacken, Berlin. Entom. Zeitschr., vol 30, 1886, p. 171.

Buitenzorg, Java, male, April 4, 1909; female, March, 1909 (Bryant and Palmer). The material offers the following measurements:

Male.-Length, $13 \mathrm{~mm}$.; wing, $11 \mathrm{~mm}$.

Female.-Length, $16 \mathrm{~mm}$; wing, $12.5 \mathrm{~mm}$. The species having never been figured, is shown in plate 45, fig. 33 . This material agrees very well with Osten Sacken's brief description of this form. His type, in the British Museum, came from Mouhot, Laos. In my material the black color includes only segments 7 and 8 of the abdomen, 9 being reddish orange like the base of the abdomen; front brown, not blackish, etc.

\section{Tribe TIPULINI.}

The question concerning the various groups of species that make up the Tipulini should be again considered. The three genera, Tipula Linnæus, Holorusia Loew, and Ctenacroscelis Enderlein, are all very closely related to one another and the slight differences that are offered for their separation are scarcely equivalent to those that distinguish genera in the Limnobinæ.

Holorusia Loew ${ }^{1}$ has the cell $R_{3}$ of the wings very narrow at its middle so that the cell is broad at both ends and shaped somewhat like an hourglass; the antennae are entirely without bristle-like hairs; femora with a semi-ctenidium of stout hairs at its tip. All of the species known to me are American (grandis Bergroth (Western U. S.) the genotype; maya Alexander (Guatemala); flavicornis Alexander (Venezuela); peruviana Alexander (Peru); orophila Alexander (Colombia); laevis Alexander (Paraguay), etc).

Ctenacroscelis Enderlein ${ }^{2}$ has the cell $R_{3}$ of the wings very narrow as in Holorusia; the antennae with scattered hairs; the femora with a ctenidium near the tip. All of the species known to me are Old World forms (praepotens Wiedemann (East Indies, Japan); monochrous Wiedemann (Java); umbrinus Wiedemann (East Indies); conspicabilis Skuse (Australia); dohrnianus Enderlein (Sumatra), the genotype; sikkimensis Enderlein (India); rex Alexander (Burma), etc.). 
It can readily be seen that the differences between Tipula and Ctenacroscelis are very slight and consist of the great arcuation of $R_{3}$ and the consequent narrowing of cell $R_{3}$ near its middle and the presence of a ctenidium near the tips of the femora. Some species of Tipula (pedata Wiedemann) have the ctenidium very poorly defined, the individual spines taking on the appearance of stout hairs; it is easy to figure out a transition into a perfectly normal Tipula.

\section{Genus PRIONOTA van der Wulp.}

Prionota van der Wulp, Notes Leyden Museum, vol. 7, 1885, p. 1.

PRIONOTA NIGRICEPS van der Wulp.

Prionota nigriceps van der Wulp, Notes Leyden Museum, vol. 7, 1885, p. 2; Tijdschr. voor Entom., vol. 28, 1885, p. 82, pl. 4, figs. 3, 4 .

One male, Mount Salak, Java, May 15, 1909; one female, Tjibodas, Mount Gedé, Java, April 20, 1909 (Bryant and Palmer). The specimens may be further described as follows:

Male.-Length, $15.8 \mathrm{~mm}$; wing, $14.8 \mathrm{~mm}$.; antenna, $6.8 \mathrm{~mm}$.

Female.-Length, $33 \mathrm{~mm}$; wing, $22.5 \mathrm{~mm}$.

The wing is shown on plate 45 , fig. 34 .

The male hypopygium is short and subglobular, the 9th tergite from above (see pl. 47, fig. 51) almost bifid by a very deep notch, the lobes black with long dense black hairs. 9th tergite and pleurite fused into one compact mass (see pl. 47, fig. 52), the pleural portion rounded with a few scattered black hairs. Pleural appendage large, flattened, rather oval, the ends somewhat pointed; the appendage is densely covered with gray hairs so as to present a silvery appearance. 9th sternite large, not projecting caudad of the pleurite.

The curious antennae whence van der Wulp derived his generic name are figured on plate 47 , fig. 50 .

It is hard to understand why Doctor Enderlein ${ }^{1}$ insists upon placing Prionota as a synonym of Prionocera Loew (=Stygeropsis Loew). The two genera have very little in common, the antennae of Prionota being provided with bristle-like hairs, those of Stygeropsis quite naked except for the usual pubescence. Prionota has a remarkable hypopygium in the male sex, the 9 th tergite deeply bilobed, the tergite fused with the pleurite, etc. Stygeropsis has a perfectly normal Tipuline hypopygium with the 9 th tergite quite distinct from the pleurite. The character of the serrations on the antennae is quite different in the two genera. It is also hard to understand why the name Prionocera is used. This name, proposed by Loew in 1844, is preoccupied by the same name used by Shuckard in the Coleoptera in $1839 .^{2}$ 
The Sumatran Prionota flaviceps Enderlein ${ }^{1}$ is quite distinct from nigriceps, which is a much larger species with a different body and wing coloration. It may be that flaviceps is not a true Prionota since it was erected on a single female specimen, in which sex the true characters of the genus are not well shown.

\section{Genus CTENACROSCELIS Enderlein.}

Ctenacroscelis Enderlein, Zool. Jahrb., vol. 32, pt. 1, 1912, pp. 1, 2.

\section{CTENACROSCELIS PRAEPOTENS Wiedemann.}

Tipula praepotens Wiedemann, Aussereur. zweifl. Insekt., vol. 1, 1828, p. 40.

Two females, Mount Salak, Java, May 15, 1909; one female, Pelaboean Ratoe, Java, October, 1909 (Bryant and Palmer). The specimens measure as follows: Length, $40 \mathrm{~mm}$.; wing, 38-40 mm. The wing is shown in plate 45 , fig. 35 .

\section{CTENACROSCELIS MONOCHROUS Wiedemann.}

Tipula monochroa Wiedemann, Aussereur. zweifl. Insekt., vol. 1, 1828, pp. 41, 42.

A male and a female, Mount Salak, May 15, 1909; a female, Pelaboean Ratoe, Java, October, 1909 (Bryant and Palmer). The wing is shown in plate 45 , fig. 36 . The following additional notes are given:

Male.-Length, $26 \mathrm{~mm}$; wing, $23.5 \mathrm{~mm}$.

Female.-Length, 33-38 mm.; wing, 24.5-25.4 mm.

The erect hairs on the thorax are very conspicuous and do not occur in the related forms.

The male hypopygium may be described as follows: 9th tergite long, deeply split by a long narrow notch for about half of its apparent length, the lobes squarely truncated at their tips and densely provided with long prostrate yellow hairs, the margin of the segment with abundant short silky hairs of a yellow color (see pl. 47, fig. 53).

9th sternite and pleurite apparently fused, at least the sternite not distinct, bearing a bifid appendage at its ventro-caudal angle (see pl. 47 , fig. 54); the outer arm of this appendage is shaped like a boomerang, the inner arm shaped as in the figure, extending caudad, entad, and dorsad, its pedicel slender, the tip expanded into a flattened lobe, whose margin is provided with groups of small black spicules. Viewed from beneath, this sterno-pleurite is deeply split medially by a V-shaped notch.

\section{CTENACROSCELIS UMBRINUS Wiedemann.}

Tipula umbrina Wiedemann, Aussereur. zweifl. Insekt., vol. 1, 1828, p. 49. Tipula castanea Macquart, Dipteres Exotiques, vol. 1, pt. 1, 1838, p. 54. Tipula congruens Walker, Proc. Linn. Soc. Lond., vol. 5, 1861, p. 231.

Ctenacroscelis sumatranus ENDERLEIN, Zool. Jahrb., vol. 32, pt. 1, 1912, p. 5.

A male and a female, Tjibodas, Mount Gedé, April 20, 1909; a male and a female, Mount Salak, May 15, 1909; a male, Depok, Java, February 10, 1909. (Bryant and Palmer.) 
This material offers the following additional data:

Male.-Length, $19 \mathrm{~mm}$.; wing, 23.5-24.5 mm.

Female.-Length, about $26 \mathrm{~mm}$.; wing, 23-25.5 mm.

The wing is shown on plate 45 , fig. 37 .

The male hypopygium may be described as follows:

9th tergite long and narrow, the caudal half deeply divided by a median split, the lobes densely clothed with long gray hairs (see pl.48, fig. 55). 9th sterno-pleurite very much as in C. monochrous Wiedemann, but the pleural appendage is quite differently shaped (see pl. 48, fig. 56), the outer arm broad, oval, the inner arm curved, its tip feebly chitinized.

It is probable that Tipula fulvolateratis Brunetti ${ }^{1}$ is synonymous with this species, though this is somewhat uncertain. This form is certainly a Ctenacroscelis, as shown by the peculiar genitalia ${ }^{2}$ the flattened 9th tergite, the long powerful 9th sterno-pleurite bearing the appendages far out at the tip of the sclerite, etc.

\section{Genus TIPULA Linnaeus.}

Tipula Linnaeus, Syst. Natur., ed. 10, 1758, p. 585.

\section{TIPULA PEDATA Wiedemann.}

Tipula pedata Wiedemann, Dipt. exot., vol. 1, 1821, p. 23; Aussereur. zweifl. Insekt., vol. 1, 1828, p. 45.

Tipulodina magnicornis EnderLeIN, Zool. Jahrb., vol. 32, pt. 1, 1912, pp. 30-32, fig. R.

Buitenzorg, Java, March, 1909, two males; April 10, 1909, one male; Pelaboean Ratoe, Java, October 12, 1909, two males and one female; Mount Salak, Java, altitude 3,000 feet, May 15, 1909, one male. (Bryant and Palmer.)

The following additional information concerning this insect is given:

Male.-Length, 16-23 mm.; wing, 15-20 mm.

Female.-Length, $30 \mathrm{~mm}$; wing, $20.5 \mathrm{~mm}$.; fore leg, femur, 19.5 mm.; tibia, $24 \mathrm{~mm}$; tarsal segment one, $20.5 \mathrm{~mm}$; tarsal segments two to five, $7.5 \mathrm{~mm}$.; middle leg, femur, $20.5 \mathrm{~mm}$; tibia, $20 \mathrm{~mm}$; tarsal segment one, $18 \mathrm{~mm}$; tarsal segments two to five, $8.5 \mathrm{~mm}$.

The wing is shown on plate 45 , fig. 38 . As there shown, the radial sector is longer than in most of the series, there being considerable variation in this respect.

The male hypopygium may be described as follows:

9th tergite having the caudal margin gently concave with a prominent median lobe whose caudal margin is again gently concave; the caudal face of the tergite densely provided with black chitinized spicules (see pl. 48, fig. 57). 9th pleurite distinct, the dorso-pleural 
suture being complete; the sclerite is covered with rather sparse long hairs (see pl. 48, fig. 58); the pleurite bears three appendages, of which the outermost is a long slender hook, incurved near its apex and here strongly chitinized; this appendage is clothed with scattered hairs along its ventral and outer edge and with numerous zigzag teeth on the inner dorsal margin (in some specimens the margin is quite smooth and straight); the tips of these long hooks in a position of rest, decussate. Inside of this long hook are two shorter appendages, the outer being the shortest and smallest, oval, pale, the tip somewhat expanded, the entire appendage with numerous long pale hairs (see pl. 48, fig. 59); the innermost appendage is a long, slender, compressed arm with an enlarged compressed head, the cephalic or dorsal side heavily chitinized, black, the remainder pale. 9th sternite long and slender, its tip projecting far beyond the remainder of the hypopygium in a long point (see pl. 48, fig. 60).

Doctor Enderlein has erected the genus Tipulodina for this insect but there seems to be no sufficient reason for retaining this name. In the first place, the name was proposed under the mistaken supposition that the insect was a Limnobine form. Secondly, none of the characters of the genus seem to differ from those of other genera, although, in some respects, the insect occupies a rather intermediate position. The straight $R_{3}$ and narrow cell 2 d $A$ are characters found in many species of Tipula; the short Rs is the common character of Pachyrhina; the shape of the cells in the median field of the wing are those of Ctenacroscelis, etc. The powerful male hypopygium and the unusual leg-coloration may offer generic differences, but until the related forms (venusta Walker, inordinans Walker, cinctipes de Meijere, gracillima Brunetti, patricia Brunetti, and others) are studied it would be decidedly premature to recognize the genus Tipulodina.

The rather curious pupa of Tipula pedata has been described as follows by de Meijere: ${ }^{1}$ The remarkable pupa of $T$. pedata found in a pot of stagnant water with water-plants (Salatiga, Java, January, van Leeuwen). The pupal skin sent to me is $34 \mathrm{~mm}$. long and $4 \mathrm{~mm}$. broad, of a blackish brown color. The very long and slender, setaceous, arcuated breathing-horns are very remarkable; they measure $11 \mathrm{~mm}$. in length, are of a blackish brown color, only the extreme tip which is slightly expanded is yellow; elsewhere they are almost uniform in diameter throughout except toward the base, where they are a very little enlarged. The dorsal abdominal segments bear a cross-row of tooth-like projections before the caudal margin of each; the ventral segments are quite similar, but here the median teeth on the hinder segments are longer and with a pair of shorter appendages before them. The tip of the abdomen likewise presents a number 
of tooth-like lobes. Along the lateral margin, each segment bears on either side two short tooth-like appendages, one being on the anterior half, the other on the posterior half of the segment.

Lest the student attribute too much significance to this condition of the pupa, quite different from the normal Tipula pupa with its short breathing-horns, I will mention a pupa of an undetermined Tipuline that is before me at this time. The specimen was taken by Dr. J. Chester Bradley at Tallulah Falls, Georgia, June 17, 1910; the stigmal horns measure $19 \mathrm{~mm}$. in length, the tip slightly expanded as in pedcta. I do not know what species this represents, Brachypremna having been reared and there are very few other species that this could represent.

\section{TIPULA UMBRINOIDES, new species.}

Antennal flagellum bicolored; no dark stripe on the thoracic pleura.

Male.-Length, $17 \mathrm{~mm}$; wing, $18.5 \mathrm{~mm}$. This species bears a close superficial resemblance to Ctenacroscelis umbrinus Wiedemann, differing as follows:

Segments of the antennal flagellum bicolored, the extreme basal portion of each segment dark brown, the remainder of the segment dull yellow (in umbrinus the flagellum is uniformly dark brown). Pleura darker brown and without a dark stripe so characteristic of umbrinus. Femora without a ctenidium. Wings (see pl. 46, fig. 39) with a brown cloud in cell $M$ near its end; a second cloud in $C u$ at about two-fifths the length; venation, cell 1 st $M_{2}$ sharply pointed at its base, radial sector short and straight. Male hypopygium with the 9 th tergite dark brown, the tip pale with numerous black chitinized spicules at the tip and underneath; the tergite is short (see pl. 48 , fig. 61 ), the visible portion a little shorter than wide and the caudal margin merely concave, not bifid. Pleural appendages (see pl. 48, fig. 62), the outer lobe pale light yellow, oval, the tip a little pointed; the inner appendages two, shaped as in the figure; the larger of the two appendages densely provided with long reddish brown hairs which project beyond the genital chamber. Ninth sternite with a dense brush of pale hairs near the tip.

\section{Habitat.-Java.}

Holotype.-Mount Salak, Java, July 4, 1909, altitude above 3,000 feet (Bryant and Palmer).

Type.-Cat. No. 19027, U.S.N.M.

\section{TIPULA GEDEHANA de Meijere.}

Tipula gedehana de Meisere, Tijdschr. voor Entom., vol. 56, 1911, pp. 66, 67, pl. 4 , fig. 47 .

One male, Tjibodas, Mount Gedé, Java, September, 1909, altitude 4,000 feet; one male, 8,000 feet; two males and one female, 9,000 feet. (Bryant and Palmer.) 
I identify this fly as de Meijere's species because of the agreement of the wing-pattern and venation. The color of the thorax is not quite as described, being dull yellowish with rather dark brown stripes. The male sex has never been described, and I characterize it as follows, making one of the specimens the allotype. The male hypopygium is rather unusually enlarged.

Male.-Length, 11.8-15.2 mm.; wing, 17-19.1 mm.

Female.-Length, $18.4 \mathrm{~mm}$; wing, $18.2 \mathrm{~mm}$.

Male.-Antennae moderately long, if bent backward extending nearly to the wing-root; flagellar segments dark brown with a dense whitish pubescence. Thorax with the ground color grayish yellow, the stripes brown. Femora with a dark brown tip. Abdomẹn brown, segments 6 to 9 , almost black. The other characters are as described by de Meijere.

The male hypopygium may be described as follows:

8th tergite with the ventral margin produced ventrad into a rounded lobe provided with a great brush of long yellow hairs; shaped as in the figure (seepl.49, fig. 63). 8th sternite deeply V-shaped beneath, its caudal margin with a dense brush of long yellow hairs. 9 th tergite very deeply split by a $\mathrm{V}$-shaped notch, the margins of the lobes adjoining the notch with numerous pale yellow hairs. 9th pleurite rather small (see pl. 49, fig. 64), the pleural appendages two; the outermost appendage is a slender, fleshy lobe, slightly curved, directed dorsad and the tip slightly cephalad; the inner appendage is large, flattened, the dorso-cephalic angle produced into a more chitinized point shaped as in the figure.

Doctor de Meijere's type was taken at the crater of Mount Gedé in 1893.

TIPULA SUNDA, new species.

Color of the thorax light gray without stripes; wings light gray, stigma distinct, vein $R_{2}$ atrophied at its tip.

Male.-Length, $14 \mathrm{~mm}$; wing, $14.2 \mathrm{~mm}$. Frontal prolongation of the head light gray above, brown on the sides, palpi dark brown. Antennae with the scapal segments light yellow, the flagellum broken. Head light gray.

Pronotum dull yellow. Mesonotal praescutum and scutum clear light gray without apparent stripes; scutellum yellowish brown; postnotum dull brownish yellow, very indistinctly dusted with gray. Pleura dull light yellow, the posterior sclerites weakly dusted with gray. Halteres light yellow, the knob brown. Legs, coxae and trochanters dull light yellow, femora dark brown, only the extreme base a little paler, tibiae and tarsi dark brown. Wings light gray, costal cell more yellowish, stigma dark brown, a clear spot beyond the stigma, veins dark brown; the veins $C$ and $S c$ more yellowish; venation (seepl. 46, fig. 40), tip of $R_{2}$ beyond the cross-vein $r$ atrophied; cell 1 st $M_{2}$ small. 
Abdominal segments dull yellow, tergites 6 to 8 black, 9 dark brown. Hypopygium: 8th tergite very narrow above, on the sides attaining the 8 th sternite. 8th sternite with the caudal margin rather squarely truncated, provided with a few hairs. 9th tergite (see pl. 49, fig. 65) rather large, subquadrate, the caudal margin deeply concave, fringed with short hairs; the caudo-lateral angles of the sclerite produced caudad into short points; a weak median impression. 9th sternopleurite (see pl. 49, fig. 66) rather large, subrounded, the pleural suture incomplete, rather short, running ventrad; outer pleural appendage elongate oval, pale, with numerous long blackish hairs, the base suddenly constricted; the inner appendage is compressed, chitinized, especially on the cephalic end where it fits into the notch of the 9 th tergite.

Habitat.- Java.

Holotype.-Tjibodas, Mount Gedé, Java, altitude 9,000 feet. (Bryant and Palmer.)

Type.-Cat. No. 19028, U.S.N.M.

The specific name, sunda, is that of the original inhabitants of western Java-Sundanese, or "men of the soil."

This species suggests $T$. cinereifrons de Meijere ${ }^{1}$ from Java and Borneo, but in that species the thorax is dull reddish yellow, not gray. In cinereifrons, also, the tip of $R_{2}$ is atrophied beyond the cross-vein $r$.

TIPULA FLAVICOSTA, new species.

Coloration dull reddish yellow, thorax without stripes; wings subhyaline with the costal cell yellow, petiole of cell $M_{1}$ very short.

Female.-Length, $13 \mathrm{~mm}$; wing, $13.8 \mathrm{~mm}$. Frontal prolongation of the head rather short, brown, the palpi very long, light brown. Antennae with the two basal segments dull yellow, the flagellum broken. Front dull yellowish, the posterior portions of the head grayish.

Thoracic dorsum dull reddish yellow with distinct suggestions of greenish which are probably abnormal. Pleura rather dull yellowish brown. Halteres brown. Legs, coxae and trochanters dull yellow, remainder of the legs brown. Wings with a light brown suffusion, the costal cell light yellow, stigma brown; venation: (see pl. 46, fig. 41), terminal portion of $R_{2}$ beyond $r$ distinct; cell 1 st $M_{2}$ very small, pentagonal; the petiole of cell $M_{1}$ very short, less than the cross-vein $m$ or $r-m$; the fork of $M_{1}$ very deep; cell $2 n d A$ very narrow.

Abdomen dull brownish yellow, darkening into brown on tergites 4 to 9 , the apical sclerites almost black, shiny; ovipositor with the tergal valves long, gently curved downward at their tips, the sternal valves short, only about half the length of the tergal valves. 
Habitat.-Java.

Holotype.-Pelaboean Ratoe, Java, October 16, 1909. (Bryant and Palmer).

Type-Cat. No. 19029, U. S. N. M.

Closest to cinereifrons de Meijere which has the tip of vein $R_{2}$ atrophied, the petiole of cell $M_{1}$ long, etc. The species may be separated by the key given later on.

TIPULA TJIBODENSIS, new species.

Color dull yellowish brown without distinct stripes; wings subhyalixe, stigma and costal region dark brown; abdomen reddish yellow excepting segments 6 to 8 which are black.

Male.-Length, $12 \mathrm{~mm}$.; wing, 14.6-15 mm.

Female.-Length, $14.6 \mathrm{~mm}$.; wing, $12.4 \mathrm{~mm}$. Frontal prolongation of the head short and stout, yellowish, palpi pale brown. Antennae short, if extended backward scarcely attaining the wing-root, the first three segments dull yellow, the remaining segments of the flagellum with the basal third black, remainder yellow, on the apical segments passing into brown. Head dark brown, the front and occiput brighter.

Thoracic dorsum dull yellowish brown, the stripes very indistinct. Pleura dull yellow. Halteres brown. Legs, coxae and trochanters dull yellow, remainder of the legs broken. Wings subhyaline or faintly brownish; costal cell and stigma dark brown, tip of the wing suffused with brown, most distinct on the outer half of cell $R_{2}$; venation as in plate 46 , fig. 42 .

Abdominal segments 1 to 5 dull brownish yellow, the basal sclerites somewhat brighter; 6 to 8 black; 9 reddish yellow. Hypopygium: 9 th tergite deeply three notched (see pl. 50, fig. 68) the median notch deepest and broadest, its margin chitinized and receiving the tip of the powerful inner pleural appendage; 9 th sternite powerful (see pl. 50, fig. 69) the pleurite completely severed by the pleural suture; pleural appendages complex, shaped as in the figure, the inner lobes compressed, chitinized, a two-pronged black hook on the outside. A group of long conspicuous hairs at the dorso-cephalic angle of the pleurite.

Habitat.-Java.

Holotype.-Male, Tjibodas, Mount Gedé, Java, altitude 4,500 feet (Bryant and Palmer).

Allotype.-Female, topotypic.

Paratype.-Male, topotypic.

Type.-Cat. No. 19030, U. S. N. M.

This species suggests cinereifrons de Meijere in the color of the thorax but the dark costa will separate this species off from related forms including flavicosta, new species, which has the costa yellowish. 
TIPULA SALAKENSIS, new species.

Size very small (wing of the male about $8.5 \mathrm{~mm}$.) ; thorax shiny reddish yellow.

Male.-Length, $7.8 \mathrm{~mm}$; wing, $8.3 \mathrm{~mm}$. Frontal prolongation of the head very short, reddish brown. Antennae elongated, if bent backward nearly attaining the base of the abdomen; basal segments dull yellow, flagellar segments elongated, dark brown. Head with the front reddish yellow, the vertex and occiput dull gray.

Thorax shiny, reddish yellow, without distinct darker stripes. Pleura lighter yellow. Halteres, stem yellow, knob dark brown. Legs, coxae, and trochanters yellow; femora yellow at the base, passing into brown at about midlength; tibiae and tarsi brown. Wings with a slight suffusion of brown, stigma large, distinct, veins dark brown; venation: (see pl. 46, fig. 43), $R_{2}$ beyond $r$ distinct; cell 1st $M_{2}$ small; petiole of cell $M_{1}$ short, about as long as cell 1 st $M_{2}$; cross-vein $m$-cu punctiform or obliterated; cell 2 nd $A$ very narrow.

Abdomen reddish yellow, segments 6 to 9 dark brownish black. Hypopygium (see pl. 49, fig. 67), the 9th tergite with a conspicuous median lobe that is expanded at its tip as shown in the figure.

Habitat.-Java.

Holotype.-Mount Salak, Java, 1909. (Bryant and Palmer.)

Type.-Cat. No. 19031, U.S.N.M.

This tiny Tipula is almost as small as T. inconspicua de Meijere, ${ }^{1}$ which has the thorax dull, with three dark brown stripes; the wing coloration and the venation of the two species is quite different.

TIPULA GEDEHICOLA, new species.

Thoracic dorsum reddish, without apparent stripes; costal cell of the wings brownish yellow.

Male.-Length, $13.5 \mathrm{~mm}$.; wing, $14.3 \mathrm{~mm}$. Frontal prolongation of the head short, reddish brown, the palpi yellowish brown. Antennae rather short, the basal segments dull yellow, the flagellar segments dark brown. Front dull light yellow, vertex and occiput yellowish gray.

Thoracic dorsum reddish yellow, the postnotum clearer yellow. Pleura reddish yellow. Halteres dark brown, the apex of the knob rather pale. Legs, coxae, and trochanters reddish yellow, the remainder of the legs broken. Wings faintly suffused with brown, the costal cell brownish yellow, stigma brown; venation as in plate 46, fig. 44 .

Abdomen reddish brown, segments 6 to 9 blackish. Hypopygium: 9th tergite from above deeply split by a median notch, the lobes evenly rounded at their tips, underneath densely provided with tiny black spicules (see pl. 50, fig. 70). 9th pleurite distinct, the pleural 
suture being complete (see pl. 50, fig. 71); pleural appendages, outermost lobe fleshy, pale, rather rectangular, the dorsocephalic angle produced, dorsad and caudad into a lobe shaped as in the figure; the inner lobe viewed from the side suggests a duck's head. 9th sternite with a dense brush of long yellow hairs from the caudal margin. (See pl. 50, fig. 72, for an enlarged view of the pleural appendages.)

Habitat.-Java.

Holotype.-Male, Tjibodas, Mount Gedé, Java, altitude 5,000 feet; April 20, 1909. (Bryant and Palmer.)

Paratype.-Sex ?, topotypic.

Type.-Cat. No. 19032, U.S.N.M.

The group of Javan Tipulae with reddish thoracic dorsa without distinct darker stripes includes cinereifrons de Meijere, gedehicola, new species; tijbodensis, new species; salakensis, new species; and flavicosta, new species. They may be separated by the following key:

1. Wings with the cell $1 s t M_{2}$ very small, pentagonal, all the sides subequal; petiole of cell $M_{1}$ not longer than the cross-vein $r \ldots \ldots \ldots \ldots \ldots \ldots \ldots \ldots \ldots$ flavicosta.

Wings with the cell 1 st $M_{2}$ not equally pentagonal, the upper face longer; petiole of

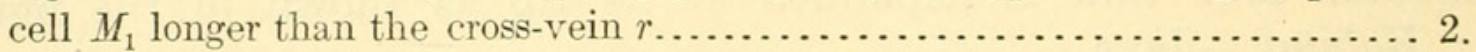

2. Antennal flagellum bicolored................................tjibodensis.

Antennal flagellum dark brown..................................... 3.

3. Size small (wing, male, under $9 \mathrm{~mm}$.).........................

Size larger (wing, male, over $12 \mathrm{~mm}$. .)............................... 4.

4. Palpi yellowish brown; tip of $R 2$ beyond cross-vein $r$ present........... gedehicola.

Palpi blackish brown; tip of $R 2$ beyond cross-vein $r$ atrophied ......... cinereifrons.

T. flavicosta, salakensis, and gedehicola have cell 2nd $A$ of the wings very narrow; T. tiibodensis has it a little broader; T. cinereifrons has it broadest, quite normal.

\section{Genus PACHYRRHINA Macquart.}

Pachyrrhina Macquart, Suite a Buffon, Dipteres, vol. 1, 1834, p. 88.

\section{PACHYRRHINA DOLESCHALLI Osten Sacken.}

Tipula javensis Doleschald, Natuurkund. Tijdschr. Nederl. Indie, vol. 10, 1856, 406 , pl. 3 , fig. 2 .

Pachyrrhina doleschalli Osten Sacken, Annal. Mus. Civ. Genova, vol. 16, 1881, 399.

Pachyrrhina fallax van der WulP, Bijdragen tot de Dierk., vol. 17, 1904, p. 90.

Two females that agree with the description of this form, one from Buitenzorg, June, 1909, the other from Tjibodas, Mount Gedé, Java, April, 1909. (Bryant and Palmer.) The wing is figured on plate 46, fig. 45 .

\section{PACHYRRHINA OCHRIPLEURIS de Meijere.}

Pachyrrhina ochripleuris de Meijere, Tijdschr. voor Entom., vol. 56, 1914, pp. 6-8.

Two females from Tjibodas, Mount Gedé, Java, August 26, 1909; altitude, 7,000 feet. (Bryant and Palmer). The species has not been figured and its wing is shown on plate 46 , fig. 46 . 
PACHYRRHINA IMMACULATA PANGERANGENSIS, new subspecies.

A series of four males from Pangrango, altitude 9,000 feet; a male and a female from Tjibodas, Mount Gedé, 4,500 feet; a female at the latter place from an altitude of 9,000 feet. (Bryant and Palmer.)

These agree very closely with van der Wulp's characterization of the species immaculata ${ }^{1}$ except in the larger size. $P$. immaculata is described as being small, with a length of $9.5 \mathrm{~mm}$. in the male sex. The insect before me is much larger, and I think that it is subspecifically distinct from the typical form. The material offers the following measurements:

Male.-Length, 11.6-13.6 mm.; wing, 12.5-13.6 mm.

Female.-Length, 16.5-18 mm.; wing, $17 \mathrm{~mm}$.

Type.-Cat. No. 19033, U.S.N.M.

The venation of the wing is shown on plate 46, fig. 47. The petiolate condition of cell $M_{1}$ is not found in most of the specimens of the series, this cell being normally sessile.

\section{EXPLANATION OF THE PIATES.}

\section{Plate 42.}

Fig. 1. Wing of Dicranomyia albitarsis.

2. Wing of Dicranomyia erythrina.

3. Wing of Dicranomyia excelsa.

4. Wing of Dicranomyia simplissima.

5. Wing of Dicranomyia carneotincta.

6. Wing of Geranomyia nitida.

7. Wing of Geranomyia linearis.

8. Wing of Geranomyia javanica.

9. Wing of Rhipidia javanensis.

10. Wing of Goniodineura nigriceps.

Plate 43.

Fig. 11. Wing of Libnotes, species.

12. Wing of Libnotes montivagans.

13. Wing of Libnotes nigricornis.

14. Wing of Paratropeza ornatipennis

15. Wing of Rhamphidia (Rhamphidia) apicalis

16. Wing of Rhamphidia (Eurhamphidia) niveitarsis.

17. Wing of Rhampholimnobia reticularis.

18. Wing of Antocha javanensis.

19. Wing of Atarba javanica.

\section{Plate 44.}

Fig. 20. Wing of Gonomyia (Gonomyia) bryanti.

21. Wing of Mongoma saucia.

22. Wing of Limnophila amica.

23. Wing of Limnophila palmeri.

24. Wing of Ula javanica.

25. Wing of Eriocera verticalis.

26. Wing of Eriocera acrostacta.

27. Wing of Eriocera basilaris.

28. Wing of Eriocera mesopyrrha.

29. Wing of Eriocera cingulata. 


\section{Plate 45.}

Fig. 30. Wing of Stibadocera metallica. $\quad\left(\mathrm{R}_{1}=\right.$ Radius $1 ; \mathrm{R}_{3}=$ Radius 3.$)$

31. Wing of Pselliophora ardens.

32. Wing of Pselliophora compedita.

33. Wing of Pselliophora rubra.

34. Wing of Prionota nigriceps.

35. Wing of Ctenacroscelis praepotens.

36. Wing of Ctenacroscelis monochrous.

37. Wing of Ctenacroscelis umbrinus.

38. Wing of Tipula pedata.

Plate 46.

Fig. 39. Wing of Tipula umbrinoides.

40. Wing of Tipula sunda.

41. Wing of Tipula flavicosta.

42. Wing of Tipula tjibodensis.

43. Wing of Tipula salakensis.

44. Wing of Tipula gedehicola.

45. Wing of Pachyrrhina doleschalli.

46. Wing of Pachyrrhina ochripleuris.

47. Wing of Pachyrrhina immaculata pangerangensis.

\section{Plate 47.}

Fig. 48. Hypopygium of Gonomyia (Gonomyia) bryanti.

Dorsal aspect of the pleurite.

49. Hypopygium of Gonomyia (Gonomyia) bryanti.

Appendages on the inner ventral side of the pleurite.

50. Antenna of Prionota nigriceps.

The first five segments from above.

51. Hypopygium of Prionota nigriceps.

Dorsal aspect. $\quad 9 \mathrm{pl}=9$ th pleural region; $p l a p=$ pleural appendage; $9 t p l=$ 9th pleuro-tergite.

52. Hypopygium of Prionota nigriceps.

Lateral aspect. $9 \mathrm{pl} t=9$ th pleuro-tergite; $9 s=9$ th sternite.

53. Hypopygium of Ctenacroscelis monochrous.

Dorsal aspect of the 9 th tergite.

54. Hypopygium of Ctenacroscelis monochrous.

Lateral aspect. $9 s t ~ p l=9$ th sterno-pleurite; $9 t=9$ th tergite.

Plate 48.

Fig. 55. Hypopygium of Ctenacroscelis umbrinus.

Lateral aspect. $9 s t p l=9$ th sterno-pleurite; $9 t=9$ th tergite.

56. Hypopygium of Ctenacroscelis umbrinus.

Pleural appendages in a position of rest.

57. Hypopygium of Tipula pedata.

Dorsal aspect of the 9 th tergite.

58. Hypopygium of Tipula pedata.

Lateral aspect. $8 s=8$ th sternite; $9 s, 9 p l=9$ th pleurite; $9 t=9$ th sternite and tergite.

59. Hypopygium of Tipula pedata.

Lateral aspect of the inner pleural appendages.

60. Hypopygium of Tipula pedata.

Ventral aspect of the 9 th sternite.

61. Hypopygium of Tipula umbrinoides.

Lateral aspect. $9 t, 9 s=9$ th tergite and sternite; $s t=8$ th tergite.

62. Hypopygium of Tipula umbrinoides.

Pleural appendages viewed from the inside. 


\section{Plate 49.}

Fig. 63. Hypopygium of Tipula gedehana.

Lateral aspect. $7_{s}, 7 t, 8 s, 8 t, 9 s, 9 t=$ the respective sternites and tergites; $p l=$ pleurite.

64. Hypopygium of Tipula gedehana.

The 9 th segment enlarged, lateral aspect. $9 s, 9 t=9$ th sternite and tergite; $p l=$ pleurite.

65. Hypopygium of Tipula sunda.

Dorsal aspect of the 9 th tergite.

66. Hypopygium of Tipula sunda.

Lateral aspect. $9 \mathrm{pl} s t .=9$ th sterno-pleurite. $\quad \gamma_{s}, 8 s=$ sternites; $7 t, 8 t, 9 t=$ tergites.

67. Hypopygium of Tipula salakensis.

Lateral aspect. $9 p l, 9 s, 9 t=$ sclerites of 9 th segment.

\section{Plate 50.}

Fig. 68. Hypopygium of Tipula tjibodensis.

Dorsal aspect of the 9 th tergite.

69. Hypopygium of Tipula tjibodensis.

Lateral aspect. $9 p l=9$ th pleurite. $\quad 8 s, 9 s=$ sternites; $8 t, 9 t=$ tergites.

70. Hypopygium of Tipula gedehicola.

Dorsal aspect of the 9 th tergite.

71. Hypopygium of Tipula gedehicola.

Lateral aspect. $9 \mathrm{pl} .=$ pleurite; $8 s, 9 s=$ sternites; $8 t, 9 t=$ tergites.

72. Hypopygium of Tipula gedehicola.

Lateral aspectof the pleural appendages.

$81022^{\circ}$-Proc.N.M.vol.49-15-13 

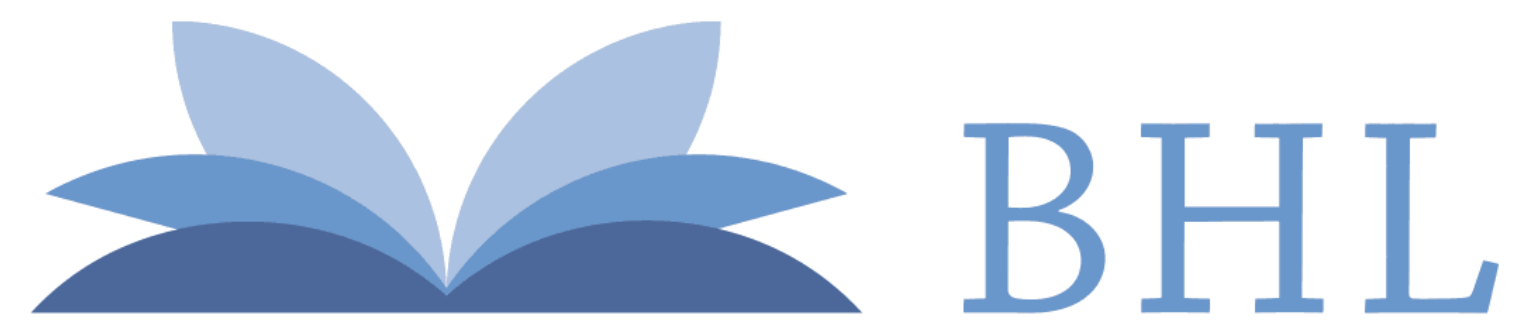

\section{Biodiversity Heritage Library}

Alexander, Charles P. 1915. "On a collection of Javanese crane-flies (Tipulidae, Diptera) in the United States national museum." Proceedings of the United States National Museum 49(2103), 157-193.

https://doi.org/10.5479/si.00963801.49-2103.157.

View This Item Online: $\underline{\text { https://www.biodiversitylibrary.org/item/53483 }}$

DOI: https://doi.org/10.5479/si.00963801.49-2103.157

Permalink: https://www.biodiversitylibrary.org/partpdf/52375

\section{Holding Institution}

Smithsonian Libraries

\section{Sponsored by}

Smithsonian

\section{Copyright \& Reuse}

Copyright Status: Public domain. The BHL considers that this work is no longer under copyright protection.

This document was created from content at the Biodiversity Heritage Library, the world's largest open access digital library for biodiversity literature and archives. Visit BHL at https://www.biodiversitylibrary.org. 